\title{
IMPLEMENTASI KONSEP TRI HITA KARANA \\ PADA AKOMODASI PARIWISATA DI NUSA DUA, BALI (Study Kasus: Melia Bali Villas and Spa Resort)
}

\author{
Dinar Sukma Pramesti \\ Email: dinar.pramesti@pib.ac.id \\ POLITEKNIK INTERNASIONAL BALI
}

\begin{abstract}
Environmental issues influence the changes in tourist consumption patterns. Tourists tend to choose tourism accommodations such as hotels that are environmentally friendly. This research aims to describe the implementation of Tri Hita Karana concept at the Melia Bali Hotel. The location of this research is in Melia Bali Villas and Spa Resort, which is classified as a 5-star hotel in Nusa Dua Bali with special achievements as the winner of Tri Hita Karana Award. This research methods is a qualitative research with descriptive data types. Data is collected using observation techniques, interviews and literature studies. The results of this study show that Melia Bali Hotel has implemented the Tri Hita Karana concept in architectural design and hotel management. This concept can increase the competitiveness of Melia Bali Villas and Spa Resort among other hotels in Bali.
\end{abstract}

Keywords: Green Hotel, Competitiveness, Hotel

ABSTRAK
Isu lingkungan mempengaruhi perubahan pola konsumsi wisatawan. Wisatawan cenderung lebih memilih akomodasi pariwisata seperti hotel yang ramah lingkungan. Penelitian ini berupaya menggambarkan implementasi konsep Tri Hita Karana di Hotel Melia Bali. Lokasi penelitian ini yaitu Melia Bali Villas and Spa Resort, yang diklasifikasikan sebagai hotel bintang 5 di Nusa Dua Bali serta mendapatkan Tri Hita Karana Award. Penelitian merupakan penelitian kualitatif dengan jenis data deskriptif. Data dikumpulkan dengan menggunakan Teknik observasi, wawancara dan studi pustaka. Hasil dari penelitian ini menunjukan bahwa Hotel Melia Bali telah menerapkan konsep Tri Hita Karana dalam design arsitektur dan manajemen hotel. Konsep ini mampu meningkatkan daya saing Melia Bali Villas and Spa Resort diantara hotel-hotel lain di Bali.

Kata kunci: Tri Hita Karana, Daya Saing, Hotel 


\section{PENDAHULUAN}

Isu lingkungan menjadi hal yang penting dalam perkembangan ekonomi global (Kirkwood and Walton, 2010). Hal tersebut disebabkan karena semakin meningkatnya pembangunan industri dan sektor lainnya yang menimbulkan berbagai permasalahan lingkungan seperti pencemaran, kerusakan sumber daya alam dan kekeringan. Isu lingkungan tersebut berdampak pada perubahan pola konsumsi wisatawan dalam memilih amenitas pariwisata seperti hotel. Rahmafitria (2014) dalam penelitiannya mengungkapkan sebagian dari wisatawan sudah mulai menjadikan parameter konsep dan manajemen ramah lingkungan sebagai salah satu tolak ukur dalam memilih sarana akomodasi.

Melihat fenomena kecenderungan perubahan pola konsumsi wisatawan tersebut, maka konsep sadar atau ramah lingkungan menjadi suatu keharusan bagi para pengelola hotel dalam menjalankan bisnisnya. Selain untuk menarik wisatawan, konsep ramah lingkungan juga memiliki nilai investasi jangka panjang yang mampu menciptakan loyalitas wisatawan, menciptakan reputasi manajemen, penghematan biaya operasional, terjalinnya hubungan dengan komunitas lokal serta mampu menciptakan manajemen yang sehat.

Bali merupakan salah satu daerah tujuan wisata favorit di Indonesia. Sebagai daerah tujuan wisata favorit, tentunya Bali memiliki banyak hotel. Menurut ketua Perhimpunan Hotel dan Restoran Indonesia (PHRI) Provinsi Bali, Tjokorda Oka Artha Ardhana Sukawati, jumlah hotel di Bali tahun 2017 baik itu hotel berbintang lima hingga non berbintang mencapai 130.000 hotel dengan total kamar kurang lebih mencapai 47 juta (Surya, 2017). Penerapan ramah lingkungan pada hotelhotel di Bali disinyalir akan mampu meningkatkan daya saing hotel itu 
sendiri maupun daya saing Bali sebagai daerah tujuan wisata yang lebih bertanggung jawab.

Hotel adalah ujung tombak pariwisata dan merupakan bagian terpenting dalam pariwisata, sebab hotel menyediakan jasa kamar, makanan, hiburan, pemandangan, cinderamata, investasi yang besar dan peyerapan tenaga kerja yang banyak, karena itu hotel pantas mendapatkan perhatian khusus. di Bali sudah ada usaha pembinaan dan pemberian penghargaan terhadap pengembangan pariwisata khususnya hotel yang menerapkan ramah lingkungan. Salah satu penghargaan yang cukup terkenal dan sesuai dengan konsep kearifan lokal Bali adalah Tri Hita Karana Awards. Program Tri Hita Karana Awards merupakan ide Bali Travel News yang diluncurkan pertama kali pada 22 Desember 2000. Peluncuran program ini dimaksudkan sebagai upaya untuk membangun pariwisata Bali yang berkesinambungan dan harmonis dengan lingkungan. Kompetisi ini mengikutsertakan hotel-hotel dan lokasi wisata di Bali untuk dapat mengamalkan sebuah konsep kearifan lokal yaitu Tri Hita Karana (THK).

THK adalah konsep trilogi pembangunan di Bali. THK menuntun adanya keharmonisan lingkungan dengan cara hidup berke-Tuhanan, menjaga kelangsungan lingkungan dan bertoleransi dalam masyarakat (Pendit, 1996: 14). Penerapan nilai-nilai THK secara sadar dan dinamis akan membangun proses hubungan kehidupan yang seimbang antara alam dan manusia. Dalam konteks kehidupan sosial, implementasi konsep THK dapat dilihat dari pelaksanaan upacara keagamaan, gotong royong dalam kehidupan masyarakat serta memanfaatkan alam lingkungan untuk kesejahteraan manusia dengan tetap memperhatikan keseimbangannya. Konsepsi THK merupakan landasan yang kuat dalam pembangunan umat Hindu di Bali (Arwati, 2006: 6). Leluhur masyarakat Bali cukup kuat mempertahankan THK dengan menjaga, memelihara dan 
melestarikannya secara turun-temurun tanpa syarat atau pamrih selain mengharapkan keselarasan hidup dalam kebersamaan di muka bumi ini.

Konsep THK sudah banyak diadaptasi oleh hotel dan resort di Bali. Salah satunya yang paling sukses mengimplementasikan THK adalah Melia Bali Villas and Spa Resort yang akrab disebut dengan Melia Bali. Melia Bali terletak di kawasan BTDC (Bali Tourism Development Corporation) Lot 1. Nusa Dua, Bali. Nusa Dua berada di Kabupaten Badung dengan letak geografis antara 8014'20" Lintang Selatan dan $115^{0} 05^{\prime} 00^{\prime}-115^{0} 26^{\prime} 16^{\prime \prime}$ Bujur Timur. Kawasan BTDC yang terletak di Nusa Dua ini merupakan kawasan sebuah enklave berisi resort besar internasional berbintang lima dan merupakan daerah tujuan wisata pantai.

Mengacu pada uraian tersebut, maka penulis mengangkat penelitian yang berjudul Implementasi Konsep Tri Hita Karana pada Akomodasi Pariwisata di Nusa Dua, Bali dengan studi kasus di Melia Bali Villas and Spa Resort. Penelitian ini diharapkan mampu memberikan gambaran mengenai akomodasi pariwisata yang menjunjung manajemen ramah lingkungan dan keberlanjutan melalui penerapan konsep masyarakat setempat yaitu konsep THK. Berdasarkan latar belakang yang telah diuraikan, maka yang menjadi permasalahan dalam penelitian ini, adalah (1) Bagaimana implementasi konsep Tri Hita Karana pada design hotel Melia Bali Villas and Spa Resort? (2) Bagaimana implementasi konsep Tri Hita Karana pada manajemen hotel Melia Bali Villas and Spa Resort?

\section{KONSEP DAN TEORI}

Konsep dan teori yang dipilih untuk menjelaskan penelitian ini terangkum sebagai berikut. 


\subsection{KONSEP TRI HITA KARANA}

Di dalam kehidupan masyarakat Hindu di Bali, kesehariannya menganut pola THK yang meliputi tiga unsur yaitu hubungan manusia dengan Tuhan (Parahyangan), hubungan manusia dengan sesama manusia (Pawongan) dan hubungan manusia dengan lingkungan (Palemahan). Parhyangan lebih menekankan agar manusia menjaga kebersihan dan kesucian dirinya secara lahir dan batin serta selalu mendekatkan diri pada Tuhan melalui tri sandhya, tirtayatra, yoga dan samadi.Pawongan melandasi rasa kasih sayang, saling menolong dan toleransi. Palemahan menekankan pada kemampuan manusia untuk memelihara, menjaga dan memperbaiki kualitas lingkungannya melalui serangkaian upacara tertentu (Gde Rai, 2010: 45).

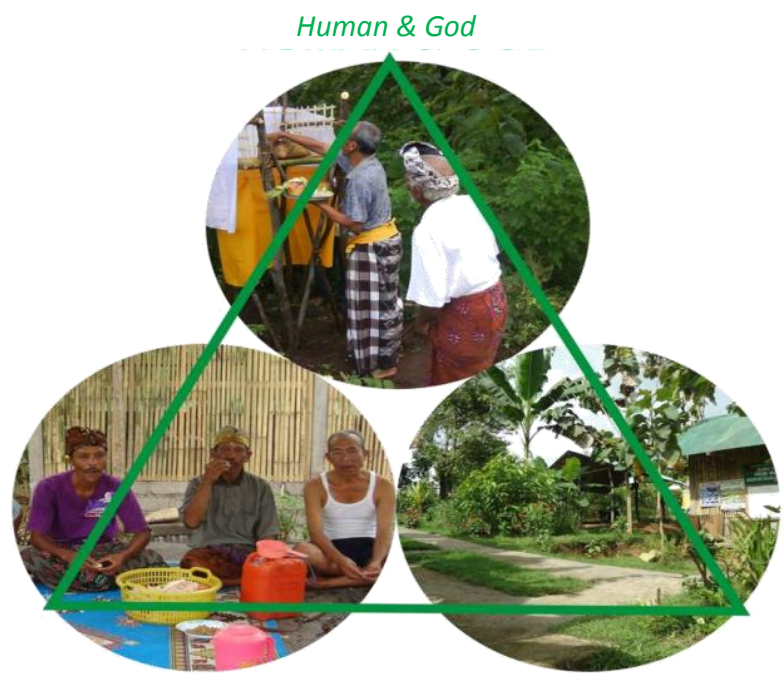

Human \& Human

Human \& Nature

Gambar 1. Konsep Tri Hita Karana

Sumber: http://www.topholidaysbali.com/wp-content/uploads/2011/11/Tri-HitaKarana-Concept-for-Life.jpg

Dasar filosofi dari THK berdasarkan pada Bhagawad Gita III. 10, yaitu unsur dari THK adalah Prajapati, Praja, dan Kamadhuk. Filosofi hidup dalam THK untuk mewujudkan sikap hidup seimbang dan 
konsisten untuk percaya dan bakti pada Tuhan, mengabdi pada sesama dan memelihara kesejahtraan alam lingkungan. Pemahaman tentang THK tidak boleh sepotong-sepotong, tetapi THK dipahami sebagai suatu kesatuan yang utuh, sinergis dan konsisten sebagai filosofi hidup yang universal (Wiana, 2007: 8).

Dalam ajaran THK yang menjadi unsur sentral adalah manusia, karena hanya manusia yang memiliki Sabda, Bayu, dan Idep. Dalam diri manusia merupakan sesuatu yang sangat kompleks karena semua yang ada di dunia ini sudah terdapat dalam tubuh manusia. Dengan ajaran THK hidup menjadi selaras dan seimbang. Setiap unit kehidupan masyarakat Hindu di Bali senantiasa mengarah kepada ajaran THK dan telah tercermin dalam hidup harmonis di masyarakat dengan suku bangsa lainnya di Indonesia, bahkan terhadap para wisatawan yang berkunjung ke Bali. Kini THK, bukan saja baik diterapkan di Bali, juga di dunia terutama yang menginginkan suasana hidup aman, tenteram, sejahtera, dan sentaosa. Hidup berdampingan secara damai.

\subsection{KONSEP AKOMODASI PARIWISATA}

Akomodasi dalam pariwisata adalah segala sesuatu yang disediakan untuk memenuhi kenutuhan seseorang ketika berwisata. Akomodasi bias berupa tempat dimana seorang wisatawan bias menginap, beristirahat, makan, minum, mandi (Munavizt, 2009). Definisi akomodasi pariwisata lainnya adalah suatu tempat penginapan yang dilengkapi pelayanan lainnya seperti layanan makan dan minuman. Contoh akomodasi pariwisata adalah hotel, bungalow, losmen (SK Menteri Pariwisata No. 37/PW.304/MPT/86). Berdasarkan Pengertian akomodasi pariwisata tersebut, dalam penelitian ini ranah akomodasi pariwisata di khususkan yaitu akomodasi pariwisata berupa hotel. 


\subsection{KONSEP HOTEL}

Definisi Hotel menurut Prastowo dan Suryo (2002:11), "Hotel adalah penginapan yang diwajibkan memenuhi aturan yang berlaku dalam menawarkan penginapan, makanan dan perlindungan atas barang bawaan pada tamunya. Secara fisik hotel adalah sebuah bangunan yang terdiri dari beberapa ruangan yang digunakan oleh tamu untuk beberapa saat serta menyediakan jasa serta fasilitas yang dibutuhkan oleh tamunya". Sedangkan definisi hotel menurut SK Menparpostel Nomor: KM 34/HK 103/MPT-87 adalah sebagai berikut (Sugiarto, 1997 :20): Hotel adalah suatu jenis akomodasi yang mempergunakan sebagian atau seluruh bagiannya untuk menyediakan jasa lainnya bagi umum, yang dikelola secara komersial serta memenuhi ketentuan persyaratan yang ditetapkan di dalam keputusan pemerintah

Berdasarkan uraian konsep maka, penelitian berjudul Implementasi Konsep Tri Hita Karana pada Akomodasi Pariwisata di Nusa Dua, Bali dengan studi kasus Melia Bali Villas and Spa Resort, berupaya untuk menganalisis penggunaan konsep THK di akomodasi wisata berupa hotel yaitu Melia Bali Villas and Spa Resort sebagai upaya pihak hotel dalam menerapkan pariwisata berkelanjutan. Falsafah THK telah menjadi landasan pembangunan Bali sejak tahun 1969 dan telah diimplementasikan dalam setiap aktivitas pembanguan di Bali.

THK Awards merupakan penghargaan kepada industri perhotelan di Bali yang telah menerapkan standar THK. Pihak penyelenggara menggunakan buku THK TourismAwards and Accreditations sebagai acuan bagi tim penilai dan sasaran program (objek ternilai). Poin-poin penilaian penghargaan ini meliputi tiga unsur utama: Parahyangan, Pawongan, dan Palemahan. Parahyangan mengacu pada usaha hotel dan lokasi wisata dalam menyelaraskan aktivitasnya dengan konsep-konsep ke-Tuhanan yang diterapkan di Bali (Yayasan THK 2012: 10-12), 
Pawongan mengacu pada keselarasan para pelaku pariwisata di hotel dan lokasi wisata (Yayasan THK, 2012: 13). Palemahan, mengharuskan pelaku pariwisata di hotel ataupun di lokasi wisata untuk mencintai dan menjaga alam atau selaras dengan alam (Yayasan THK, 2012: 17-20).

Kriteria THK Awards ini cukup ketat dan tidak semua hotel di Bali dapat menjadi peserta dalam awards ini, karena sebuah hotel yang baik harus berdasar atas tiga unsur utama, hotel tersebut harus memiliki konsep Pawongan, Palemahan, dan Parahyangan yang baik serta inovasi-inovasi apa saja yang dilakukan oleh hotel juga menjadi salah satu kriteria penilaian awards ini. Hotel-hotel yang memiliki lingkungan yang buruk, manajemen yang tidak baik seperti terjadi pemecatan dan pemogokan karyawan, apalagi tidak ada keharmonisan antar manajemen, tentu saja tidak diperkenankan ikut serta dalam awards ini.

Dari segi implementasinya, hotel yang baik di Bali memiliki persyaratan khusus yaitu memiliki pura, dan pura tersebut harus lengkap, untuk Parahyangan-nya, pura hotel tersebut setidaknya harus memiliki palebahan. Palemahan sebuah hotel harus mampu mengurus limbah sendiri, agar tidak sampai mencemari lingkungan. Untuk Pawongan, hotel, harus memiliki semacam suka duka ikatan dalam setiap karyawan, banjar dan warga banjar agar selalu terjalin harmonis.

Program THK Awards yang berlangsung sejak tahun 2000 hingga kini dilaksanakan secara konsisten dan simultan. Terdapat beberapa tantangan yang dihadapi dalam melaksanakan program tersebut, seperti semakin tingginya konflik kepentingan antar sektor pembangunan di Bali, serta tuntutan agar program ini dapat diimpelementasikan secara nasional dengan penyelenggaraan yang lebih profesional. Beberapa lembaga telah memberikan dukungan terhadap penyelenggaraan program ini seperti pemerintah daerah (kabupaten/kota/provinsi), lembaga swadaya masyarakat, kementrian lingkungan hidup dan budpar, dan 
organisasi internasional (WTO). Oleh karena itu, peran berbagai pihak semakin dibutuhkan dalam memberikan kontribusi yang nyata terhadap upaya-upaya penyempurnaan program ini.

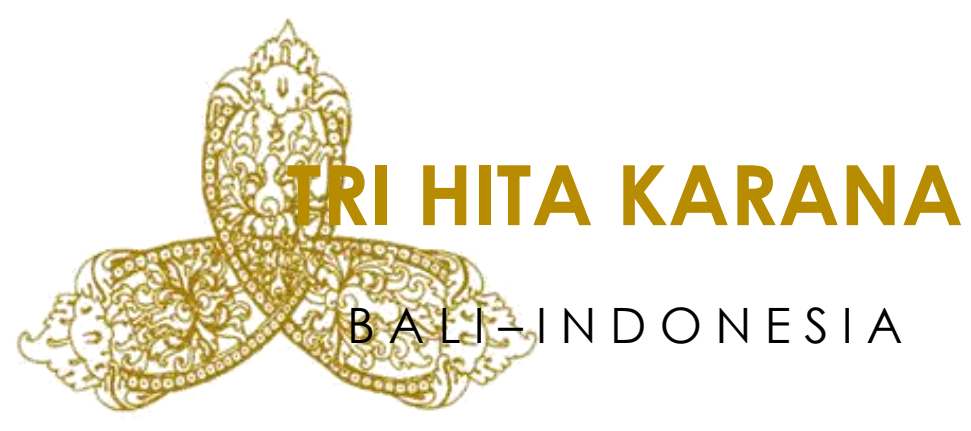

Gambar 2. Lambang Tri Hita Karana

Sumber: http://www.phribali.or.id/wp-content/uploads/2013/12/tri-hita-karana-in.jpg

\subsection{TEORI PARIWISATA BERKELANJUTAN}

Teori yang digunakan yaitu teori pariwisata berkelanjutan McIntyre (1993). Menurut McIntyre (1993: 17) dalam buku yang berjudul Sustainable Tourism Development Guide for Local Planner dinyatakan bahwa ada tiga komponen penting yang saling terkait dalam pengembangan sustainable tourism dan apabila ketiga komponen ini dilibatkan maka akan terjadi peningkatan kualitas hidup. Ketiga komponen yang dimaksud adalah

1. Industri pariwisata adalah dapat menciptakan lapangan pekerjaan, meningkatkan pendapatan, mendorong penanaman modal, meningkatkan kesempatan untuk mengembangkan bisnis.

2. Lingkungan. Agar kepariwisataan dapat bertahan lama maka tipe dan tingkat aktivitas kepariwisataan harus diseimbangkan dengan kapasitas tersedianya sumber daya, baik alam maupun buatan.

3. Masyarakat. Pengembangan kepariwisataan memerlukan perubahan yang berhubungan dengan pemeliharaan, maka perlu bagi masyarakat sekitarnya untuk memperoleh keuntungan dan kepariwisataan yang 
dapat memuaskan mereka sehingga mereka mempunyai motivasi untuk mengadakan perubahan tersebut. Peningkatan taraf hidup masyarakat adalah faktor pokok. Keinginan masyarakat untuk terlibat adalah merupakan kunci untuk mengadakan perubahan yang akan meningkatkan kualitas hidup. Jika masyarakat terlibat dalam berbagai tahap maka masyarakat akan merasa termotivasi dan bertanggung jawab. Para tertua dan orang-orang kuno memerlukan perhatian khusus, karena mereka sulit untuk menerima perubahan-perubahan. Sejak awal sebaiknya masyarakat diberikan pengertian mengenai kepariwisataan dan dampak-dampak yang mungkin terjadi, sehingga nantinya tidak akan terjadi kesalahpahaman.

\section{METODE PENELITIAN}

Sebelum dilakukan penelitian, disiapkan rancangan penelitian dengan cakupan komponen-komponen yang diperlukan. Menurut Moleong (1994: 236), rancangan penelitian dapat membimbing peneliti dalam proses pengumpulan data, analisis, dan interpretasi yang dicapai dapat digeneralisasikan terhadap situasi-situasi yang berbeda. Penelitian merupakan penelitian deskriptif kualitatif yang menjelaskan mengenai Implementasi Konsep Tri Hita Karana pada Akomodasi Pariwisata di Nusa Dua, Bali pada hotel Melia Bali Villas and Spa Resort

Terdapat beberapa langkah dalam teknik pengumpulan data. Teknik ini dapat dilakukan dengan tiga cara, yaitu observasi, survei dan dokumen (studi pustaka).

1. Observasi

Observasi menurut Keraf (1997: 162) adalah pengamatan langsung pada suatu objek yang diteliti. Dalam penelitian ini dilakukan observasi atau pengamatan langsung pada objek yang akan diteliti. Observasi yang dilakukan yaitu dengan mengamati secara langsung 
penerapan konsep THK di Hotel Melia Bali. Kegiatan observasi meliputi melakukan pengamatan, pencatatan secara sistematis kejadian, perilaku, obyek yang dilihat dan hal lainnya yang diperlukan dalam mendukung penelitian yang sedang dilakukan. Langkah awal, dilakukan observasi secara umum, kemudian dilanjutkan dengan pengumpulan data atau informasi sebanyak mungkin. Tahap selanjutnya peneliti harus melakukan observasi yang terfokus.

\section{Wawancara}

Wawancara digunakan untuk mendapatkan data yang dibutuhkaan dalam penelitian secara langsung dari objek penelitian. Wawancara merupakan komunikasi dari seseorang peneliti untuk mendapatkan informasi yang sesuai dengan yang diinginkan. Wawancara berarti komunikasi antara pewawancara dan orang yang diwawancara, hal ini cenderung menimbulkan perbedaan interpretasi antara keduanya. Namun dengan wawancara dapat diperoleh informasi yang lebih lengkap. Teknik wawancara merupakan teknik pengumpulan data dengan menggunakan pedoman wawancara. Wawancara ini dilaksanakan untuk memperoleh masukan dari pihak-pihak yang terkait untuk memperoleh data yang akan dibutuhkan untuk pembahasan penelitian. Wawancara dilakukan terhadap manajmene hotel Melia Bali. Wawancara dilakukan secara tidak terstruktur agar wawancara tidak kaku dan kegiatan ini dapat mengalir dengan sendirinya, sehingga peneliti mendapatkan pengetahuan yang lebih mendalam dan luas. Dengan mengalirnya wawancara secara alami informan akan lebih mudah dan santai dalam memberikan jawaban.

3. Studi Kepustakaan

Studi pustaka merupakan metode pengumpulan data-data yang berasal dari buku-buku literatur, majalah, internet. Keraf (1997: 165) 
mengemukakan studi pustaka adalah suatu metode pengumpulan data yang memanfaatkan buku atau literatur sebagai bahan referensi untuk memperoleh kesimpulan-kesimpulan atau pendapat para ahli dengan mendapatkan kesimpulan tersebut sebagai metode tersendiri. Sedangkan Nazir (1998: 112) studi kepustakaan merupakan langkah yang penting dimana setelah seorang peneliti menetapkan topik penelitian, langkah selanjutnya adalah melakukan kajian yang berkaitan dengan teori yang berkaitan dengan topik penelitian. Studi literatur atau pustaka adalah suatu tahapan setelah permasalahan diidentifikasi secara tepat dan benar, kemudian dicari acuan dan bahan pembanding dari buku yang telah ada sebagai penunjang. Dalam pencarian teori, peneliti akan mengumpulkan informasi sebanyak-banyaknya dari dokumentasi atau kepustakaan yang sudah ada yang merupakan hasil penelitian yang telah dibuat oleh pihak lain dan biasanya berbentuk teks. Dokumen tersebut harus memiliki relevansi dengan penelitian. Sumber-sumber kepustakaan dapat diperoleh dari buku, jurnal, majalah, hasil-hasil penelitian (tesis dan disertasi), dan sumber-sumber lainnya yang sesuai (internet, koran dll).

\section{GAMBARAN MELIA BALI VILLAS AND SPA RESORT}

Fokus lokasi dalam penelitian ini berada Melia Bali Villas and Spa Resort. Melia Bali Villas and Spa Resort terletak di kawasan wisata, BTDC Lot 1, Nusa Dua Bali. Dari Bandara Internasional I Gusti Ngurah Rai diperlukan waktu perjalanan kurang lebih 25 menit, 750 meter dari Bali International Convention Center dan 850 meter dari Bali Nusa Dua Convention Center. Akomodasi penginapan ini berada di kawasan favorit di Nusa Dua. Hotel ini termasuk hotel bintang 5, memiliki berbagai macam fasilitas yang menunjang pelayanan tamu. Saat ini, Melia Bali 
yang telah beberapa kali direnovasi memiliki 494 kamar dengan konfigurasi: 117 Superior, 247 Deluxes, 30 Family room, 26 the Level Duplex Suite, 54 Duplex Suites, 9 Deluxe and Family Suites dan 1 Executive Suite.

\section{PEMBAHASAN}

Berdasarkan hasil observasi, Melia Bali dibangun di atas tanah 26 hektar. Arsitektur yang unik ini diciptakan oleh Emilio Nadal (Spanyol), yang telah mendedikasikan setahun penuh riset dan studi tentang arsitektur Bali dan gaya hidup di Bali sebelum mengemban tugas merancang Hotel Melia Bali. Berikut hasil pengamatan terhadap Hotel Melia Bali

\subsection{IMPLEMENTASI KONSEP THK PADA DESIGN MELIA BALI VILLAS AND SPA RESORT}

Konsep awal Melia Bali adalah konsep yang ingin memberikan kesan dan pengalaman tradisional lewat THK. Melia Bali juga mempunyai komitmen terhadap lingkungan karena lingkungan merupakan aspek yang dititikberatkan dalam pembangunan berkelanjutan. Secara nasional Melia Bali telah menjadi Eco-Hotel setelah pengakuan yang diberikan oleh Badan Lingkungan Nasional tahun 2000 dan di tahun yang sama memperoleh sertifikat dari Badan Pelestarian Lingkungan Internasional Green Globe, sekaligus menjadi hotel pertama di Bali yang memperoleh sertifikat tersebut.

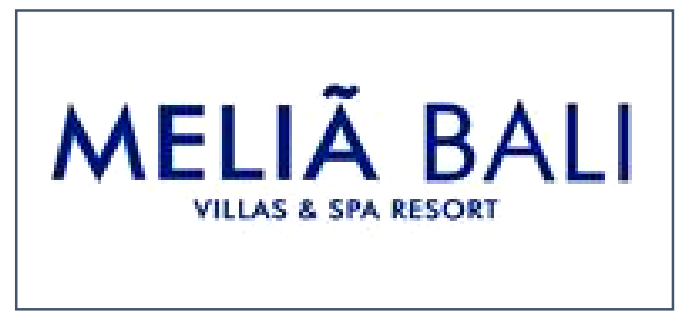

Gambar 4. Logo Melia Bali Villas \& Spa Resort

Sumber: http://www.baliplan.com/images/photo/melia-bali-new-logo.jpg 


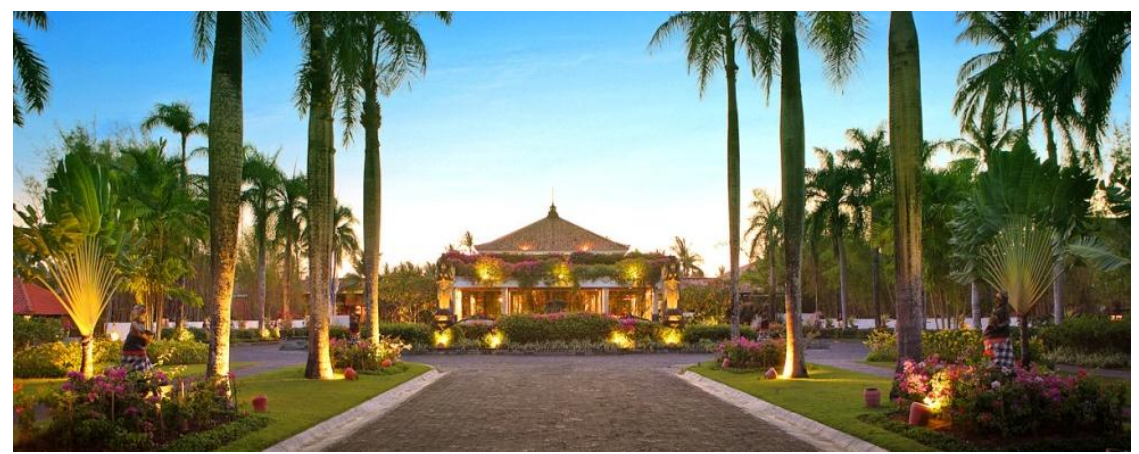

Gambar 5. Melia Bali Villas \& Spa Resort

Sumber: http://www.baliplan.com/images/photo/melia-bali-front.jpg

Komitmen Melia Bali terhadap lingkungan membuatnya dapat mencapai prestasi tiga kali berturut-turut sebagai pemenang gold (peringkat teratas) THK Awards. Saat ini Melia Bali menyandang gelar Emerald (penghargaan seumur hidup) karena telah mendapat penghargaan gold untuk yang keempat kalinya pada THK Awards 2008. Melia Bali juga menjadi yang pertama di Asia dan salah satu dari 14 hotel di dunia yang dianugerahi penghargaan tertinggi Earth Check Platinum sebagai pengakuan atas pentingnya program keberlanjutan sosial dan lingkungan.

Melia Bali membuat tamu merasakan berada di jantung dan jiwa eksotisme Bali. Terletak di Nusa Dua yang berpantai indah dengan pasir putih, terdapat taman tropis yang luar biasa subur sepanjang 10,7 ha, bangunan beratap jerami, dan menghadap laguna yang tenang, serta dikelilingi terumbu karang membangkitkan suasana tenang dan memberikan iklim alam sejati Bali. Dua patung dewi besar dan air mancur lotus mekar menyambut para pendatang baru di pintu masuk. Lobi utama resort ini memiliki nuansa Bali dengan lantai kayu, langitlangit yang tinggi, dan perabot kayu jati yang mengkilap. Pada langitlangit, para tamu dapat menyaksikan gambaran Hindu Dharma, dalam bentuk yang unik Hindu sebagai perlambang konsep THK yang 
menggambarkan keseimbangan dan hubungan yang harmonis antara manusia dengan lingkungan, manusia dengan manusia, dan manusia dan Tuhan, yang dibuat ditiga tingkatan yang berbeda pada lobi. Pada sore hari Gamelan orkestra Bali memainkan musik tradisional disertai dua gadis Bali yang menari untuk menyambut tamu

Para tamu bisa berjalan-jalan ke kamar di bawah pohon kelapa, terdapat taman subur dengan bunga-bunga tropis dengan aksentuasi kolam ikan koi dan ukiran jembatan batu. Perabotan dan peralatan khas Bali memberikan sentuhan asli otentik tersendiri untuk hotel ini. Setelah menjalani renovasi pada tahun 1996, 2004 dan 2010 sentuhan Bali ditingkatkan dengan fasilitas kenyamanan dan kemewahan lain, seperti set televisi baru, program satelit internasional, akses internet Wi-Fi seluruh resort dengan kehidupan dan keindahan taman hotel tetap dijaga.

Apa yang membedakan resort ini dari pesaing lain adalah senantiasa menciptakan 'Momen Meliá', yang membuat orang-orang merasakan keinginan untuk kembali ke Melia Bali. Inilah cerminan dari sebuah surga, sebuah karya alam yang selaras dengan karya manusia. Resort ini memadukan alam dan kenikmatan liburan dalam kesatuan memukau tumbuhan yang hijau dengan hangatnya senyuman pelayanan.

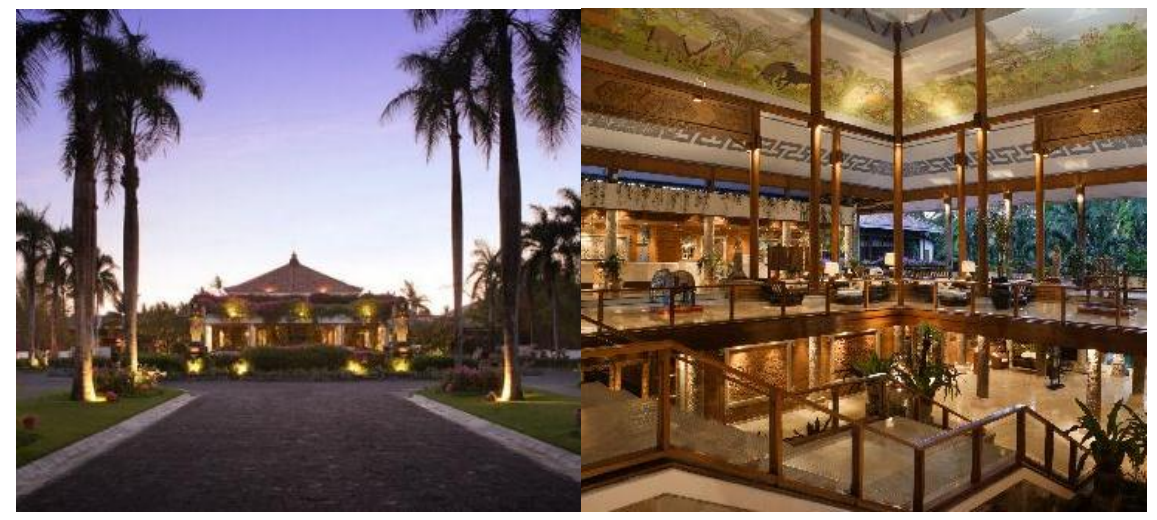

Gambar 6. Tampak Depan dan Interior Lobby Melia Bali Sumber: http://www.asiarooms.com/en/hotel-reservations/171931_meliabali-indonesia-bali.aspx 


\subsection{IMPLEMENTASI KONSEP THKPADA MANAJEMEN MELIA BALI VILLAS AND SPA RESORT}

Dalam penelitian ini implementasi Konsep THK dilihat pada Manajemen hotel Melia Bali yang dibagi menjadi tiga yaitu dilihat dari segi parahyangan, palemahan dan pawongan mengacu pada konsep THK. Dilihat dari Parahyangan adapun kegiatan yang dilakukan manajemen Melia Bali yaitu dengan menyediakan sarana persembahyangan bagi karyawan sesuai dengan agama dan kepercayaan yang dianut karyawannya sehingga karyawan dapat melakukan kegiatan persembahyangan setiap hari secara periodik, mengadakan kegiatankegiatan yang mendukung hubungan karyawan dengan Tuhan seperti mengadakan darma wacana secara teratur, melakukan kegiatan tirta yatra, memberikan kesempatan bagi karyawan Muslim yang menjalankan puasa Ramadhan, mengadakan buka puasa Bersama maupun merayakan hari besar keagamaan. Karyawan Melia Bali juga diwajibkan mengembangkan sikap toleransi dan solidaritas doantara para karyawan dengan menghadiri kegiatan keagamaan dari salah satu agama yang lain.

Dalam melaksanakan konsep THK yaitu Palemahan ada beberapa kegiatan yang dilakukan. Kegiatan-kegiatan tersebut telah berhasil membawa Melia Bali mencapai $12 \%$ pengurangan konsumsi energi, 5\% pengurangan dalam penggunaan air, $78 \%$ pengurangan limbah padat. Berikut uraian kegiatan yang dilakukan Melia Bali terkait konsep THK palemahan:

a) Penghematan energi dan sumber daya alam

Melia Bali menerapkan efisiensi energi dan mengurangi emisi gas rumah kaca. Melia Bali dapat mencapai penghematan energi sebesaar $336.276 \mathrm{kWh}$ dengan mengurangi jam operasional pencahayaan dan mengganti keefisiensian pencahayaan. Dengan rincian: Mengganti lampu taman 1000, 80W dengan 23W, 
Mengganti spot lamps 1200, 50W dengan 1.5W lampu LEDc, mengganti incandescent lamps 291, 60W dengan 11W PLCd, mengurangi jumlah lampu di bagian back office. Melia Bali juga melakukan instalasi fasilitas hemat air seperti air penabung pada keran kamar mandi dan otomatis timer untuk penyiraman taman, melakukan pemeriksaan kebocoran di semua outlet air secara mingguan dan melaksanakan program pelatihan bagi seluruh karyawan serta membuat program khusus bagi karyawan untuk menyumbangkan ide-ide baru untuk mengurangi konsumsi energi dan memberikan pemahaman penghematan energi

b) Pengelolaan sampah dan limbah

Pengelolaan sampah yang dilakukan Melia Bali yaitu terkait dengan program reuse, reduce, dan recycle. Adapun praktek yang dilakukan yaitu: Reduce dilakukan untuk mengurangi penggunaan bahan-bahan yang bisa merusak lingkungan. Melia Bali menerapkannya dengan membuat peraturan untuk mengurangi jam operasional laundry pada saat tingkat hunian kamar kurang dari 70\%. Hal ini dapat mengurangi limbah yang berasal dari sabun cuci pakaian yang dihasilkan oleh laundry tersebut. Melia Bali juga mengurangi penggunaan pestisida yang mengandung zat berbahaya jika penggunaannya melampaui batas. Reuse dilakukan Melia Bali dengan memanfaatkan Teknik capturing rain water dan memanfaatkan air daur ulang melalui BTDC untuk pengadaan $65 \%$ air bersih untuk kepentingan operasionalnya. Recycle dilakukan Melia Bali dengan melaksanakan program pengurangan limbah padat dengan cara memisahkan limbah organik dan non-organik. Sehingga limbah organik tersebut dapat didaur ulang menjadi kompos dan dimanfaatkan untuk pemeliharaan taman hotel. Melia Bali juga melakukan daur ulang terhadap penggunaan kertas yang banyak berasal dari back office. 
c) Melaksanakan penghijauan dan penyehatan lingkungan.

Hotel Melia Bali melakukan Corporate Social Responsibility (CSR) di bidang lingkungan dengan melakukan penanaman pohon, melakukan kegiatan bersih-bersih di pantai di sekitar kawasan BTDC.

Melia Bali Villas \& SPA Resort Nusa Dua-Badung merupakan salah satu hotel berbintang lima dan bertaraf internasional di Bali yang mengutamakan pengelolaan karyawan secara baik dan profesional. Resort ini memiliki karyawan yang berjumlah 563 orang dan terbagi dalam lima belas departemen pada tahun 2016. Dalam melaksanakan konsep THK yaitu Pawongan, manajemen melakukan berbagai kegiatan seperti:

a) Melia Bali memahami bahwa kegiatan dalam masyarakat harus berkontribusi untuk mengurangi perbedaan sosial dan mengurangi kemiskinan, melalui kesempatan untuk pertumbuhan ekonomi yang saling menguntungkan dengan masyarakat lokal. Berdasarkan hal tersebut maka Meli Bali melaksanakan program CSR dengan memberikan beasiswa sekolah untuk karyawan dan anak dari karyawan hotel yang kurang mampu untuk melanjutkan sekolah, dan membantu masyarakat miskin

b) Melia Bali berupaya peka terhadap kebutuhan sosial karyawan dan ingin berbagi komitmen dengan karyawan, menampung kekhawatiran karyawan untuk solidaritas. Beberapa kegiatan yang dilakukan Melia Bali untuk memfasilitasi karyawan adalah dengan menyediakan kotak saran bagi karyawan, membentuk komite untuk menangani fasilitas bagi karyawan, menyediakan ruangan/tempat istirahat, rekreasi bagi karyawan, membentuk perkumpulan suka duka bagi karyawan, mengadakan kegiatan piknik untuk karyawan dan keluarga, melakukan pengembangan karyawan dengan cara melakukan pelatihan sesuai dengan pekerjaannya., mengikutsertakan 
karyawan dalam berbagai lomba/kejuaraan di luar perusahaan seperti lomba bartender, memasak, menata kamar.

c) Melia Bali berupaya untuk dekat dengan para pemangku kepentingan, mendengarkan, dan mengenal lebih baik; itu sebabnya Melia Bali selalu memiliki sikap didekati terbuka.

Berbagai upaya yang telah dilakukan Melia Bali tersebut dapat dilihat keseriusan dan komitmen Melia Bali untuk mencapai keseimbangan antara kebutuhan generasi sekarang dan masa depan, antara pembangunan ekonomi, sosial budaya dan lingkungan dan pelestarian, dan antara memuaskan kebutuhan pemangku kepentingan. Melia Bali mengidentifikasi dampak lingkungan dari operasi pada lingkungan alam, mengurangi dan membantu untuk melestarikan keanekaragaman hayati. Melia Bali berusaha untuk efisiensi energi dan penggunaan yang bertanggung jawab dari sumber daya. Semua upaya tersebut telah membuahkan hasil sehingga Melia Bali mendapat berbagai pengahrgaan dibidang lingkungan.

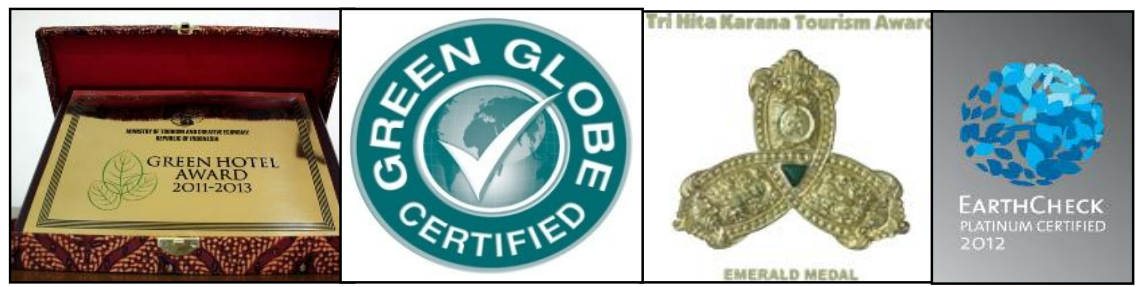

Gambar 7. Penghargaan Melia Bali

Sumber: http://www.www-balitravelnews.com/wpcontent/uploads/2012/01/4.jpg

\section{PENUTUP}

Dari hasil pembahasan mengenai THK dan implementasikannya pada studi kasus Melia Bali dapat disimpulkan dua hal, yaitu sebagai berikut:

1. Melia Bali mengimplementasikan THK pada konsep awal didirikannya Melia Bali. Hal ini karena melia Bali memiliki visi 
untuk menciptakan suasana dan pengalaman tradisional Bali dimana nuansa itu tertuang dalam THK yang diimplementasikan di hotel. Implementasi konsep THK dapat terlihat pada design arsitektur Melia Bali. Konsep ini sengaja diterapkan karena berpengaruh pada keberlanjutan pembangunan budaya Bali. Dengan implementasi tersebut keseimbangan spiritual, manusia dan alam telah tercapai dan berpengaruh terhadap keberlanjutan.

2. Tujuan filosofi dan visi Melia Bali sama dengan konsep THK yaitu mencapai tujuan resort yang berkelanjutan dan menjaga kelestarian budaya Bali. Melia Bali dengan sungguh-sungguh menerapkan konsep THK tidak hanya pada design arsitektur tetapi juga pada manajemen hotel seperti dalam pengelolaan sampah, efisiensi energi, efisiensi air, pengelolaan limbah, sehingga Melia Bali mampu mendapatkan THK Awards dengan penghargaan tertinggi Emerald pada tahun 2004, setelah sebelumnya meraih peringkat Gold selama tiga tahun berturut-turut.

Konsep THK hendaknya diterapkan secara luas sebagai strategi bersaing yang efektif untuk meraih pangsa pasar yang pro- keberlanjutan dan kondisi pasar yang semakin berkembang terhadap kepedulian lingkungan. Dalam kasus ini, THK yang diterapkan oleh industri hotel di Bali memiliki tanggung jawab untuk menyediakan kualitas pengalaman berwisata dengan menjaga keseimbangan antara tujuan pemangku kepentingan untuk mengejar pertumbuhan destinasi dengan keberlanjutan sumber daya. Keberlanjutan menjadi sangat relevan dalam pengembangan kepariwisataan karena produk pariwisata di Bali berbasis pada alam dan budaya, sehingga sektor perhotelan sangat berkepentingan pada pelestarian sumber daya tersebut. Terlebih lagi tren pengembangan produk wisata menunjukkan nature and people contact yang semakin menentukan motivasi wisatawan untuk mengun- jungi suatu hotel. 


\section{DAFTAR PUSTAKA}

Agenda 21 Sektoral 2000. Agenda Pariwisata Untuk Pengembangan Kualitas Hidup Secara Berkelanjutan.

Charter, M. 1992. Greener Marketing: A responsible Approach to Business. Sheffield. UK: Greenleaf Publishing.

Coddington, Walter 1993. Environtmental Marketing: Postive Strategies for Reaching Green Consumer. New York: Mc Graw-Hill.

Graci, S. \& Dodds, R. 2008. Innovations and Barriers to Achieving Sustainable Tourism in Island Destinations. Refereed conference Proceedings. The greening of industry conference. leeuwarden, The Netherlands June 26-28, 2008.

Gunn, Clare A., and Turgut Var. 2002. Tourism Planning: Basics, Concepts, Cases. London: Routledge.

Inskeep, E. 1991. Tourism Planning: An integrated and sustainable development approach. New york.

ivanovic. M., at al. 2009. Tourism Development Fresh Perspectives. Pearson Education and Prentice Hall.

ottman, J.A. 1993. Green Marketing, Challenges \& opportunities for the New Marketing Age. Chicago: NTc Business Books, (chapter 3).

Panduan Penilaian Green Hotel Award. 2011. Direktorat Standardisasi Pariwisata Kementerian Kebudayaan dan Pariwisata.

Peattie, K. 1995. Environmental Marketing Management: Meeting the Green Challenge. Pitman.

Picard, Michael. 1992. Pariwisata Budaya dan Budaya Pariwisata. Jakarta: Kepustakaan Populer Gramedia.

Sujatno, Bambang A. Mensikapi Jogja dari Sisi Bisnis Hospitality. Makalah Seminar. Dipresentasikan pada 16 Juli 2008 Diselenggarakan oleh Perhimpunan Hotel Restoran indonesia (PHRI BPD Bali).

Sprastayasa, I Gusti NA. 2008. Mass Tourism atau Quality Tourism: Sebuah Pemikiran untuk Pengembangan Pariwisata bali Masa Depan. Jurnal Ilmiah Kepariwisataan. Vol. 13 No. 1 Maret 2008 (32-44). Jakarta: 1P3M STP Tri Sakti.3

Kementerian Lingkungan Hidup. 2012. Revitalisasi Sistem Amdal. (serial online). [cited 2012 Sep. 29]. Available from URL: http://www.menlh.go.id/amdal/.

Anonim. 2012. Why Should Hotels Be Green? (serial online). [cited 2012 Sep. 28]. Available from URL: http://www.greenhotels.com. 


\section{PROFIL PENULIS}

Dinar Sukma Pramesti, ST.,MT lahir di Denpasar 12 September 1988. Menyelesaikan Pendidikan Sekolah Dasar hingga SMA di Bali. Menamatkan Sarjana Teknik Arsitektur di Universitas Udayana pada tahun 2010. Melanjutkan Pendidikan Magister di bidang arsitektur dengan mengambil konsentrasi Arsitektur Kajian Lingkungan Binaan Etnik di Pascasarjana Universitas Udayana yang diselesaikan tahun 2013. Memiliki pengalaman sebagai arsitek selama 3 tahun di sebuah perusahaan arsitek, kontraktor, konsultan dan design planning di Denpasar. Pernah bekerja selama 5 tahun sebagai asisten Prof. Dr. Ir. Sulistyawati, M.S., M.M., M.Mis., D.Th., Ph.D, seorang Profesor yang aktif dalam membuat buku dan penelitian di bidang arsitektur dan pariwisata. Pengalamannya ini membawanya menjadi Dosen D4Manajemen Perhotelan di Politeknik Internasional Bali mengajar mata kuliah Seni Budaya Bali dan Metodologi Penelitian. 